\title{
Sporda Hormonal Etkileşim ve Cinsel Davranış
}

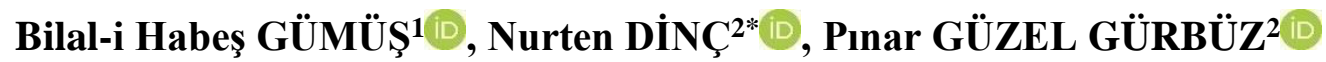

\author{
${ }^{1}$ Manisa Celal Bayar Üniversitesi, Tip Fakültesi, Manisa. \\ ${ }^{2}$ Manisa Celal Bayar Üniversitesi, Spor Bilimleri Fakültesi, Manisa.
}

Derleme

Gönderi Tarihi: 09.09.2020
Kabul Tarihi: 30.11.2020
Online Yayın: 31.12.2020

\section{$\ddot{O} \mathbf{z}$}

Bu çalışmanın amacı seksüel aktivitenin ve insan biyokimyasında davranışlara yön veren ve üreme güdüsünü biçimlendiren hormonal değişimlerin sportif aktivite ile olan ilişkilerini güncel literatür verileri içerisinde gözden geçirmektir. Testosteron ve östrojen, sırasıyla testisler ve yumurtalıklar tarafından salgılanan cinsel steroidlerdir. Testosteron, erkeklerde hem anabolik (doku oluşturma) hem de androjenik (eril özelliklerin destekleyicisi) steroiddir. Protein sentezini uyararak kas kütlesi artışını sağlamaktadır. Antrenmanın testosteron sekresyonu üzerindeki etkileri incelendiğinde akut egzersizler sonrasında testosteron seviyelerinde artış görülürken kronik egzersizler sonrasında araştırmalarda çelişkili sonuçların ortaya çıktığı ve bu çelişkili sonuçların sporcunun fitness seviyesi, antrenman hacmi ve yoğunluğu ve aşırı antrenman durumundan kaynaklandığı görülmektedir. Ayrıca performansı arttırmak amacıyla dışarıdan alınan kullanımı yasaklı olan anabolik-androjenik steroidlerin uzun süreli kullanımları birçok tıbbi probleme neden olmaktadır. Cinsiyet değişimleri ve sportif aktivite birlikteliği için daha geniş hasta gruplarına ve parametrelerine ihtiyaç olduğu çok açıktır. Genç spor bilimcilerin yaşadıkları toplumun geleneksel yargı değerlerini dikkate alarak bu alanlarda yeni çalışmalar yapması bilime katkı sağlayacaktır. Unutulmaması gereken sağlık ve spor birlikteliğinin sürdürebilir olması için orta ve düşük yoğunluklu sporun risk kat sayısının da düşük olduğudur.

Anahtar Sözcükler: Hormanal değişiklikler, sportif aktivite, seksüel aktivite, trans bireyler.

\section{Hormonal Interaction and Sexual Behavior in Sports}

\begin{abstract}
This study aims to review the relationship between sexual activity and hormonal changes that shape behavior and reproductive drive in human biochemistry with sportive activity in the sphere of the current literature data. Testosterone and estrogen are sexual steroids secreted by the testicles and ovaries, respectively. Testosterone is both anabolic (tissue building) and androgenic (supportive of masculine properties) steroid in men. It stimulates protein synthesis and increases muscle mass. When the effects of training on testosterone secretion are examined, it is observed that there is an increase in testosterone levels after acute exercises, while contradictory results appear in research after chronic exercises, and these contradictory results are due to the athlete's fitness level, training volume and intensity and excessive training status. Besides, long-term use of anabolic-androgenic steroids, which are banned from outside use to increase performance, causes many medical problems. Larger patient groups and parameters are needed for gender changes and association of sportive activity. Young sports scientists will contribute to science by carrying out new studies in these areas by considering the traditional judicial values of the society in which they live. It should be noted that the risk coefficient of medium and low intensity sports is low for the health and sports association to be sustainable. Key words: Hormonal changes, sportive activity, sexual activity, trans individuals.
\end{abstract}

*Sorumlu Yazar: Nurten DİNÇ, Doç. Dr., E-posta: nurten.dinc@ hotmail.com 


\section{GíRIŞ}

Eski zamanlardan itibaren sportif aktivitenin başarı ölçütünü etkileyen davranış modellerinin fizyolojik ve psikolojik boyutları, çeşitlilikleri araştırılmıştır. Günümüzde bu konu ile ilgili daha geniş ölçütlere dayalı çalışmalar da devam etmektedir. İnsanların normal cinsel davranış modellerinin çeşitliliği günlük yaşam içinde herkesin alışkanlıklarına göre şekillenmektedir. $\mathrm{Bu}$ çeşitlilik ve değişikliğin temelinde; kültürel, sosyal, dinsel inanış ve öğretilerin etkin belirleyici olması yatmaktadır. Bu yadırganacak sosyal bir durum değildir. Amatör veya profesyonel bir uğraş biçimi olarak sportif yarışmaların içinde yer alıyorsanız cinsel aktivite alışkanlıklarının nasıl düzenleneceğine yönelik araştırma ve rehberlik yapacak bir yol haritası bulmak modern yaşam bağlamında bile zorluk göstermektedir. Çünkü konunun mahremiyetine olan saygıdan ötürü gönüllü kişilere ulaşmak zordur, çok dikkat istemektedir.

Bu makaledeki amaç seksüel aktivitenin ve insan biyokimyasında davranışlara yön veren ve üreme güdüsünü biçimlendiren hormonal değişimlerin sportif aktivite ile olan ilişkilerini güncel literatür verileri içinde gözden geçirmektir. Spor antrenörlerinin, teknik eğiticilerin ve bilim insanlarının ilgilendikleri, cevabını bulmaya çalıştıkları sorulardan birisi de seksüel aktivitenin yarışma öncesinde atletik performansı etkileyip etkilemediğidir. Günümüz sportif aktivitelerinin bir yönünün ekonomik olduğu dikkate alınırsa kazanma ve başarı finansal açıdan önem kazanmaktadır (Zavorsky ve Newton, 2019). Konuyla ilgili yayınlanmış veri sayısı azdır. Bu çalışmalardaki metodolojik farklılıklardan dolayı net bir görüş ortaya konulmasını da zorlaştırmaktadır.

\section{Sportif Aktivite ve Hormonal Sistem}

Testosteron, erkeklerde en güçlü anabolik hormondur. Antrenmanın testosteron sekresyonu üzerindeki etkileri, sporcunun fitness seviyesine, antrenmanın hacmine ve yoğunluğuna ve aşırı antrenman durumuna göre olarak değişiklik göstermektedir (Kraemer, Fleck ve Deschenes, 2011). Sportif aktivite ile erkeklerde ana androjen olan testosteron seviyeleri arasında ki ilişkiyi açıklayan bilgiler günümüz literatüründe oldukça fazla bulunmaktadır. Konu ile ilgili çalışmalar ilgili bilim dalları tarafından ayrıntılı olarak incelenmiş̧ir (Wood ve Stanton, 2012). Testosteronu; anne karnında fetüs üzerindeki etkilerinden başlayarak erkek fenotipine yapmış olduğu değişikliklerden sorumlu olan bir hormon olarak dikkatlice değerlendirmek gerekmektedir.

Testosteron başlıca testislerde yer alan Leydig hücrelerinden salgilanmaktır. Seminifer tubuluslarda ise spermatozoo üretimi olmaktadır. Günlük testosteron salgılanması yaklaşık olarak $5 \mathrm{mg}$ /gündür ve günlük salgılanmasında bir düzen söz konusu değildir. Dalgalı aralıklı ve pulsatil salgılanma özelliği taşımaktadır. Vücutta testosteron reseptörü içeren hedef dokularda iki ana metabolite dönüşerek aktif rol oynamaktadır. Birinci metabolit aktif testosteron olan dihidrotestosterondur. Diğeri ise östradiyoldür. Dihidrotestosteron, testosterondan daha güçlü bir 
androjenik özelliğe sahiptir. Testosteronun salgılanması hipotalamus, hipofiz ve testis üzerinden olmaktadır. Hipotalamus üzerine olan negatif feedback mekanizmasıyla salınımı düzenlenmektedir. Androjen reseptörüne testosteron bağlanarak negatif feedback mekanizması ile doğrudan hipotalamus üzerinde etki gösterirken, östradiol ise negatif feedback vasitasıyla hipofiz üzerinden etki gösterir (Turek, 2014). Normal ve sağliklı çalışan bir hipotalamus hipofiz - testis aksı erkeklerde üreme, bağışıklık ve kas iskelet sisteminin fonksiyonları için temeldir. Kadınlarda; Lüteinizan hormonu (hipofizden salgılanır) ovulasyonda Theca hücrelerinden androjen salgilanmasindan ve corpus luteumun devam etmesinden sorumludur. Folikül uyaran hormon ise androjenlerin östradiole çevrilmesini ve foliküllerin gelişimini uyarmakla görevini yapmış olur (Sokoloff, Misra ve Ackeman, 2016).

Endojen testosteron salınımı erkeklerde; vücut kompozisyonuna (kas büyümesi, yağ kitlesi, kemik mineral dansitesi) direk etkilidir. Aynı zamanda merkezi sinir sistemi üzerinde onun gelişimini uyararak fonksiyonlarını düzenler (davranış modellerini, saldırganlık ve isteklilik). Ayrıca testosteron hormonal aktivitesiyle glukoz metobolizması üzerinde de etkili olur. Kemik iliği üzerine etki ederek alyuvar yapımını ve psikolojik olarak da strese karşı davranışlarımızın modellenmesini düzenlemektedir (Bhasin vd., 2001; Di Luigi, Romanelli, Sgro ve Lenzi, 2012; Zitzmann ve Nieschlag, 2003). Dışarıdan testosteron verildiğinde erkeklerde kas kütlesinde ve kas performansında artışa neden olmaktadır. Erkek sporcular aldıkları direnç eğitimi ile birlikte dışarıdan testosterona maruz kalırlarsa hem kas kütlelerinde hem de sportif performanslarında bir üst seviyeye çıktıkları bilinmektedir (Sokoloff vd., 2016; Blazevich ve Giorgi, 2001). Literatürde yapılmış olan çalışmalar göstermiştir ki akut egzersizler; total testosteron ve serbest testosteron seviyelerinde artışlara neden olmaktadır. Haftada 8 saat üzeri antrenman yapan sporcularla, haftanın çoğu günlerinde 30 dakikadan az antrenman yapan sporcular karşılaştırıldığında serum total testosteron seviyelerinde 8 saat üzeri antrenman yapan sporcularda artış olduğu bulunmuştur (Di Luigi vd., 2012; FitzGerald, Robbins, Kesver ve Xun, 2012; Sokoloff vd., 2016). Akut egzersizler hipotalamus-hipofiz-testis aksı üzerinden serum testosteron seviyelerinin yükseltmektedirler.

Kronik egzersizin total testosteron seviyeleri üzerine etkisini araştıran birçok çalışma literatürde bulunmaktadır. Geriye dönük veya çapraz kişisel çalışmalarda kronik antrenmanlı bireylerle kontrol grupları arasındaki testosteron seviyelerinde kronik antrenmanlı sporcuların aleyhine düşük testosteron seviyeleri tespit edilmiştir. İleriye dönük planlanmış yapılan çalışmalarda ise sonuçlar çelişkilidir. Bu sonuçların çalışma dizaynlarının farklılığına bağlı olabileceği gibi antrenman yoğunluğu, süresi ve antrenman konsantrasyon düzeyleri ile ilişkili standardizasyon eksikliğinden dolayı olduğu düşünülmektedir (Grandys vd., 2009; Kraemer ve Ratamess, 2005; Sokoloff vd., 2016). Bu olayın fizyopatolojik açıklamasında; kronik egzersizin, hipolatamushipofiz-testis aks1 üzerinde olan olası negatif etkisi ve bunun prolaktin sekresyonunun artmas1 sonucu doğrudan hipotalamus üzerine negatif etki göstermesi, bunun yanı sıra leptin, ghrein sekresyonlarının lüteinizan hormonun üzerine olan inhibitör etkisinden de kaynaklanabileceği ileri sürülmektedir (Hackney, 2008; Safarinejad, Azma ve Kolahi, 2009; Sansone vd., 2018). 
Kadın sporcuların hormon - antrenman ilişki durumu erkek sporcular kadar çok yaygın çalışılmamıştır. Yapılan az sayıdaki çalışmalarda her iki cinsteki bazal hormonların fenotipik özelliklere bağımlı olmasının bununla bir ilişkisi olabilir. Literatürdeki iki geniş denek sayılı çalışmada akut egzersiz nöbetlerin kadın sporcularda da hem total hem de serbest testosteron düzeylerini arttırdığı yönündedir (Cumming, Wall, Galbraith ve Belcastro, 1987; Nindl vd., 2001). Kadın sporcularda esas çalışılması gereken hormonlardan birisi de östradiyoldur. Bir menstrüal siklüs boyunca değişimler gösterse de antrenman-östradiyol seviyesi kadın sporcular için değerlendirilmelidir. Literatüre göre akut egzersizler sonrası östradiyol seviyelerinde artış olmaktadır. Bu artış erkekten farklı olarak egzersiz esnasında kadınlarda daha fazla yağ ve daha az karbonhidrat oksidasyonu nedeniyle ortaya çıkmaktadır (Sokoloff vd., 2016). Ayrıca östradiyol, egzersiz stresine karşılık kaslar için koruyucu olarak işlev görmektedir. Kesin mekanizma aydınlanmış olsa da östradiyol oksitatif hasara karşı antioksidan ve kas iskelet hasarlarını onarıcı olarak davranış sergilemektedir. Menopozda kas kitlesinin azalmasının östrojen seviyesinin düşmesine bağlı olduğu teyit edilmiştir (Enns ve Tiidus, 2010; Velders ve Diel, 2013).

Genel olarak bakıldığında sporun (antrenman bazında) yoğunluğuna bağlı olarak erkeklerdeki spermiyogram parametreleri üzerinde; DNA fragmantasyon artışı, sperm konsantrasyon azalışı, sperm morfolojik bozukluğunda artış, sperm motilitesinde azalmalara yol aştı̆̆ yapilan birçok çalışmada raporlanmıştır (Sansone vd., 2018).

\section{Sporda Performans artırıcilar}

Anabolik - androjenik steroidler (AAS) testosteronun sentetik türevleridir. Temel fizyolojik etkilerinin, hedef dokudaki bir hücre içi proteine hormon bağlanması yoluyla oluştuğu düşünülmektedir. $\mathrm{Bu}$ hormon reseptör kompleksi daha sonra kromatin üzerindeki bağlanma bölgelerine taşınır, gen transkripsiyonunu ve daha sonra mRNA sentezini düzenler (Bahrke ve Yesalis, 2004). Bilim insanları steroidleri anabolik etkileri en üst düzeye çıkarmak ve androjenik etkileri en aza indirmek için geliştirdiler. Başlangıçta uzun süreli yatak istirahati sonucu atrofi yaşayan hastalarda doku büyümesini desteklemek için geliştirilmiştir. Çok geçmeden, bu anabolik steroidlerin sporcularda kas kütlesi ve gücü geliştirmeye yardımcı olabileceği düşüncesi oluşmuştur (Powers ve Howley, 2018). En yaygın olarak, AAS'ler oral yoldan veya kas içi enjeksiyon yoluyla alınır. Daha yakın zamanlarda, jel ve kremler elit sporcular tarafından ilaç testini atlatmak amaciyla kullanılmaktadır (Bahrke ve Yesalis, 2004). Anabolik - androjenik steroid ilaçların kötü kullanımı tüm ülkeler için halen bir sorun olarak masada durmaktadır. $\mathrm{Bu}$ amaç dışı kullanımı üç ana başlık altında toplamak mümkündür (Di Luigi vd., 2012).

1. Sportif performansi artıric1,

2. Kas hacmini artırıc1, kozmetik vücut görünümü iyileștiricisi,

3. Yaşlı bireylerin gençlik özlemlerine destek sağlayıcılar olarak. 
Anabolik-androjenik steroidlerin alışkanlık olarak uzun süreli kullanımları tıbbi problemleri beraberinde getirmektedir. Endojen testosteron seviyelerini düşürerek hipogonadizme, ereksiyon problemlerine ve fertilite üzerinde de olumsuz etkilere yol açmaktadırlar. Adelosan çağdaki bireyler bu seroidlere maruz kalacak olursa kemik gelişiminde erken epifiz kapanmalarına bağlı olarak boz uzaması duracak, aşırı kıllanma, testislerde atrofi gibi ciddi tıbbi problemler ortaya çıkabilecektir. Yetişkinlerin bu steroidleri kullanmaktan vazgeçtiklerinde tıbbi problemlerin düzenlenmesi bir yıla yakın bir süreyi alabilmektedir.

Kötü amaçlı kullanılan bazı farmakolojik ajanlar aşağıda verilmiş̧ir (Di Luigi vd., 2012; Sansone vd., 2018).

a) Anabolik-androjenik steroidler

b) Diüretikler

c) Beta blokörler

d) Merkezi sinir sistemi uyarıcıları(amfetamin)

e) Fosfodiesteraz tip5 inhibitörleri (Sildenafil, tadalafil, verdanafil)

f) Karnitin

g) Kreatinin, aminoasitler, soya ve süt proteinleri.

\section{Kadın sporcularda ağızdan alınan doğum kontrol ilaçlarının etkileri}

Oral yoldan doğum kontrol yöntemi uygulayan kadın sporcuların kullandıkları bu ilaçlarla ilgili yapılan farmakolojik çalışmalar önemli bir alandaki bilgi eksikliğini doldurmaktadırlar. Crewther ve diğerlerinin (2018) yaptıkları çalışmada tükürükteki testosteron seviyelerine oral doğum kontrol ilaçlarının etkilerini değerlendirilmiştir. Sportif performans ölçümlerini kontrol grubuyla karşılaştırdıkları bu çalışmada oral kontrol doğum ilacı kullanmayan kontrol gruplarının tükürük testosteron seviyeleri, kullananlara göre müsabaka öncesinde $\% 35$ daha yüksek bulunmuştur. $\mathrm{Bu}$ değerler her iki gruptaki müsabaka performans değerlendirilmesi üzerinde etki farklıllğ 1 göstermemiştir. Yazarlar testosteron seviye farklılıklarının, bu grup yarışmacılar üzerinde performanslarına etkisinin olmadığı kanaatine varmışlardır (Crewther, Hamilton, Kilduff, Drawer ve Cook, 2018).

\section{Yarışma öncesi seksüel aktivite yarışma performansını etkiler mi?}

Zavorsky ve diğerlerinin (2018) yapmış olduğu çalışmada; 10 evli çift üzerinde (ortalama yaş: $28 \pm 7$, vücut kitle endeksi $25.5 \mathrm{~kg} / \mathrm{m}^{2}$ ), seksüel aktivite sonrası performans, denge, çeviklik testlerini içeren 6 farklı parametre ile karşılaştırılmıştır. Araştırma sonuçlarında seksüel aktivitenin 6 farklı parametreyi içeren fiziksel performans testinin hiçbirini negatif yönde etkilemediğini ve yarışmadan önceki 24 içinde gerçekleştirilen seksüel aktivitenin fiziksel performans üzerinde etkisinin olmadığını belirtmişlerdir (Zavorsky ve Newton, 2019). Yarışma öncesi seksüel aktivite ve sportif performans ilişkisi içeren bir meta analizde ise; metodolojik yetersizliklere karşılık hem erkek hem de kadın yarışmacılar üzerinde seksüel ilişsinin sportif 
performansı negatif etkileyecek bir bulguya ulaşmadıklarını, seksüel ilişkinin kişilerin kendi cinsel yaşamlarının bir döngüsü olarak değerlendirilmesi gerektiği rapor edilmiştir. Spor yarışması ile seksüel ilişki arasında (kişilerin zararlı alışkanlıkları yok ise) birkaç saatlik bir ara, süre geçmesinin faydalı olacağı önerilmektedir. Bu süre 2 saatin altında olursa yarışmacının performansının negatif yönde etkileneceği ve seksüel ilişkinin etkisinin doğrudan aerobik ve kuvvet performansı üzerine olacağı yönündedir (Stefani, Galanti, Padulo, Bragazzi ve Maffulli, 2016). Buna karşıllk 1997'de Krieger seksüel ilişki sonucunda oluşan ejakulasyonun vücuttan testosteron seviyesini düşürdüğünü ve bununda sporcu agresifliğinin, kas kuvvetinin azaltılması yönünde etki gösterdiği yorumunda bulunmuştur (Krieger, 1997). Günümüzde yapılan çalışmalar 1şığında ki bilgilerimize göre seksüel ilişki ile olsun veya olmasın oluşan ejekulasyon sonucu serum testosteron seviyelerinde herhangi bir düşmenin olmadığıdır.

\section{Seksüel aktivite ne kadar enerji harcatır?}

Seksüsel aktivite de harcanan enerji miktarını, 2013 yılında Frappier ve diğerleri sağlıklı genç çiftlerde araştırmışlardır. Yapılan bu araştırmada 21 sağlıklı genç çiftin ortalama yaşları 22.6 yıl iken birliktelikleri bir yıldan biraz daha fazladır. Deneklere SenseWare kol bandı uygulanarak seksüel aktivite boyunca dayanıklılık egzersizlerinde dikkate alınan parametreleri içeren kalp hızı, solunum sayısı, harcanan enerji miktarı ölçümleri yapılmıştır. Ölçümlerde, erkeklerde seksüel aktivite boyunca harcanan ortalama enerji $101 \mathrm{kCal}$ ve $4 \mathrm{kcal} / \mathrm{dk}$ olarak, kadınlarda ise $69.1 \mathrm{kcal}$ ve $3.1 \mathrm{kcal} / \mathrm{dk}$ olarak bulunmuştur. Bunların MET cinsinden değerleri ise; 6.0 MET erkek, 5.6 MET kadın olarak hesaplandı. $30 \mathrm{dk}$ 'lık koşu bandında yoğun egzersiz programında harcanan enerji ise erkeklerde $276 \mathrm{kcal}$ ve $9.2 \mathrm{kcal} / \mathrm{dk}$, kadınlarda ise $213 \mathrm{kcal}$ ve $7.1 \mathrm{kcal} / \mathrm{dk}$, MET olarak sırasıyla erkeklerde 8.5 MET karşlık kadınlarda 8.4 MET olmuştur. Araştırmacılar sonuç olarak seksüel aktivite de harcanan enerji miktarını ortalama $85 \mathrm{kcal}$ ya da $3.6 \mathrm{kcal} / \mathrm{dk}$ değeri ile ortalama bir yoğunluktaki egzersiz programına yaklaşık olarak karşılık geldiğini rapor etmişlerdir (Frappier, Toupin, levy, Aubertin-Leheudre ve Karelis, 2013).

\section{Sporda yeni problemler: transseksüel bireyler}

Spor müsabakalarında kadın ve erkek cinsiyet ayrımı fenotipik ve hormonel özelliklerin kazandırdığı vücut yapısı nedeniyle doğru bir karardır. Transseksüalite normal bir cinsiyete ait bir bireyin kendini diğer cinsiyetin üyesi olarak kabul ettiği durumdur (Gooren, 2008). Trans bireyler doğum cinsiyetleri ile deneyimli cinsiyetleri arasında uyumsuzluğa sahip olan kişilerdir. Günümüzde son rakamlara bakılacak olursa, Avrupa'daki birçok ülkede sayıları giderek artmaktadır. Hollanda kaynaklı bir yayında doğumda erkek olarak doğanların \%4.6'nın, kadın olarak doğanlarında \%3.2'nin de kararsız bir cinsiyet kimliğine sahip oldukları bildirilmiştir (Kuyper ve Wijsen, 2014). Sayılarının artışına bağlı olarak yaşamış oldukları topluluklarda görünürlükleride artmaktadır. Psiko-sosyal açısından bakıldığında cerrahi müdahale ile deneyimli cinsiyetlerine geçmiş olmalarına rağmen toplum tarafindan kabullenmelerinde hala 
sorun vardır. Bu yeni kimliklerin sonucunda toplumsal ön yargı, ayrımcılık, hoşgörüsüzlük ve bazen de hukuki davalara konu olmaları kaçınılmaz olmaktadır. Trans kişilerin bu dışlanma durumlarından kaçınabilmek için hayat tarzlarını çeşitlendirme amaçlı olarak hem bedensel hem de ruhsal iyi hissetme adına sportif amaçlı faaliyetlere yönelmektedirler. Her ne kadar çoğu amatör düzeyde hobi olarak bu aktiviteleri yapmış olsalar da bir kısmı yarışmacı sporcu kimliği ile sportif yarışmalarda yer alma isteği içinde olmaktadırlar (Jones, Arcelus, Bouman ve Haycraft, 2017). Bu probleme çözüm olarak 2004 yılında Uluslararası Olimpiyat Komitesi (IOC), bu bireylerin tüm tıbbi tedavilerini, cerrahi girişimlerini tamamlayarak sportif yarışmalara katılabileceklerini kabul etmiştir (Gooren, 2008; Ljungqvist ve Genel, 2005; Reeser, 2005). Bu kriterler daha sonra yeniden 2016 yılında transseksüel sporcular lehine rehabilite edilmiştir.

Ergenlik çağına kadar erkek ve kız çocukları aynı kas, kemik kütlesine sahiptirler. Ergenlik çağına ulaşıp testosteron maruziyetine uğrayan erkek çocuklar kas, kemik kütle ağırlığında kızlara göre daha avantajlı konuma geçmektedirler. Postpubertal dönemde transseksüel tıbbi ve cerrahi tedavi alan bireylerin erkekten kadın cinsiyetine dönüşümünde cerrahi öncesinde anti androjen+ östradiyol tedavisine alınmaktadırlar. Cerrahi olarak cinsiyet düzeltimini takiben anti antrojen kesilir ve östradiyol tedavisi devam eder. Kadından erkek cinsiyete düzenlemede medikal tedavi; her iki haftada bir 250mg testosteron kas içi enjeksiyon olarak uygulanır. Yumurtalıkların alımını takiben hipogonadal erkeklere uygulanan tıbbi tedavi benzeri testosteron uygulaması normal fizyolojik sınırları içinde kalınması koşuluyla devam edilir (Gooren ve Bunck, 2004). Gooren ve diğerlerinin (2004) yaptığı 17 kadından erkeğe dönüşen hastalar ile 19 erkekten kadına dönüştürülen hastalara uygulanan tıbbi + cerrahi tedavi sonucunda; kas kütlesi, hemoglobin seviyesi ve insülin benzeri büyüme faktörünün ölçümleri 1 yıl sonra bazal seviyeleri ile karşılıklı olarak değerlendirilmiştir. Dikkati çeken bulgu; tedaviden bir yıl sonrasında bile, erkekten kadına dönüştürülen bireylerdeki kas kütlesi, kadından erkeğe dönüşen ve androjen alan bireylerin bazal kas kütlesinden istatiksel olarak yüksek olmasıdır. Bu durum üç yıllık tedavi sonrasında bile hiçbir zaman bazal kadından erkek trans kas kütlesi seviyesine inmediğidir (Gooren ve Bunck, 2004). Bu durum erkekten kadına dönüşen transseksüel sporcuların kas kütlesi olarak kadın sporcuların kas kütlesinden daha üst düzeyde olacağını göstermektedir. Yüksek hacimli kas kütlesi antiandrojen tedaviye karşılık kadın sporcuların bazal kas kütle seviyelerine inmemektedir. Bu sonuca göre her ne kadar yeni cinsiyeti kadın olan genotipik erkek sporculara bir avantaj sağlayabileceği şeklinde yorumlanabilir. Daha kesin sonuçlara varabilmek için daha çok vakalı ve kas-kütle performans ilişkisini değerlendiren ileri boyutlu çalışmalara ihtiyaç vardır. Lapauw ve diğerlerinin (2008), erkekten kadınlara transseksül kişiler üzerindeki çalışmalarında; a) Gonodal hormon konsantransyonları b) kas-kemik kütle ölçümleri ile ilgili olarak cinsiyet değişim ameliyatlarında 3 yıl sonrası dikkate alınarak değerlendirilmiştir. Çalışma grubu 46 kişiden oluşan bu araştırmada değerler kontrol grubuyla karşılaştırılmalı olarak çalışılmıştır. Sonuçta kontrol grubuna göre düşük kas kütle hacmi ve buna bağlı olarak düşük kas gücüne sahip oldukları bulunmuştur. Yazarlar fiziksel ve sportif aktivitedeki azalan bu performanslarının düşük testosteron seviyeleri ile ilintili olduğunu rapor etmişlerdir (Lapauw vd., 2008). Bu trans kişilerin sporcu olmasalar bile kas-kemik kütlesi ve metabolizmasındaki bu 
azalmanın günlük hayat kalitelerini negatif yönünde etkileyebileceği öngörülebilir. Bu kişilerin bundan dolayı ileriye dönük kemik sağlığı açısından destek tedavilerine ihtiyaçları olabilir. Bu fizyopatoji dikkate alınarak sporcu transseksüellerin antrenman streslerine karş1 gösterebilecekleri direnç ve antrenmanı sürdürebilme kabiliyetleri aynı sporu yapan trans olmayan sporculara kıyasla güçlük çıkarabilir. Sportif hasarların görülebilme oranlarının bu grupta daha yüksek düzeyde olabileceği öngörülmektedir.

\section{SONUÇ}

Spor ve sağlıklı beden arasında her zaman için bir paralellik ve bütünlük olması gerekir. Eski bilgilerin yenileriyle değişimi spor yapan kişilerin yarışma seviyelerini daha iyi düzeylere getireceği açıktır. Olimpiyat köylerinin sporcuların aileleriyle birlikte olacak şekilde düzenlenmesi sporcunun beden ve moral motivasyonu için pozitif değer katacaktır. Sportif faaliyetlerin süresinin ve yoğunluğunun hormonal konsantrasyon değerleriyle yeniden gözden geçirilmesi gerekmektedir. Bazı maddelerin kötüye kullanımları önlenmeli ve olası tehlikeleri açısından ilgili tarafların bilgilendirilmesi zorunludur. Spor profesyonel olarak yaşam boyu sürdürülememektedir fakat bu maddelerin yaptığı hasarlar kalıcı olabilmektedir. Cinsiyet değişimleri ve sportif aktivite birlikteliği için daha geniş hasta gruplarına ve parametrelerine ihtiyaç olduğu çok açıktır. Genç spor bilimcilerin yaşadıkları toplumun geleneksel yargı değerlerini dikkate alarak bu alanlarda yeni çalışmalar yapması bilime katkı sağlayacaktır. Unutulmaması gereken sağlık ve spor birlikteliğinin sürdürebilir olması için orta ve düşük yoğunluklu sporun risk kat sayısının da düşük olduğudur.

Çıkar Çatışması: Yazarlar arasında herhangi bir çıkar çatışması bulunmamaktadır.

Yayın Etiği: Mevcut çalışmanın yazım sürecinde "Yükseköğretim Kurumları Bilimsel Araştırma ve Yayın Etiği Yönergesi" kapsamında bilimsel, etik ve alıntı kurallarına uyulmuş olup; toplanan veriler üzerinde herhangi bir tahrifat yapılmamış ve bu çalışma herhangi başka bir akademik yayın ortamına değerlendirme için gönderilmemiştir. 
Gümüş, B.H., Dinç, N. ve Güzel Gürbüz, P. (2020). Sporda hormonal etkileşim ve cinsel davranış. Avrasya Spor Bilimleri ve Ĕ̈itim Dergisi, 2(2), 107-117.

\section{KAYNAKÇALAR}

Bahrke, M. S. ve Yesalis, C. E. (2004). Abuse of anabolic androgenic steroids and related substances in sport and exercise. Current opinion in pharmacology, 4(6), 614-620. Doi: 10.1016/j.coph.2004.05.006.

Bhasin, S., Woodhouse, L., Casaburi, R., Singh, A. B., Bhasin, D., Berman, N., ... ve Dzekov, J. (2001). Testosterone dose-response relationships in healthy young men. American Journal of PhysiologyEndocrinology and Metabolism, 281(6), 1172-1181. Doi: 10.1152/ajpendo.2001.281.6.E1172.

Blazevich, A. J., ve Giorgi, A. (2001). Effect of testosterone administration and weight training on muscle architecture. Medicine \& Science in Sports \& Exercise, 33(10), 1688-1693.

Doi: 10.1097/00005768-200110000-00012.

Crewther, B. T., Hamilton, D., Kilduff, L. P., Drawer, S., ve Cook, C. J. (2018). The effect of oral contraceptive use on salivary testosterone concentrations and athlete performance during international field hockey matches. Journal of science and medicine in sport, 21(5), 453-456.

Doi: 10.1016/j.jsams.2017.09.017. Epub 2017 Sep 29.

Cumming, D. C., Wall, S. R., Galbraith, M. A., ve Belcastro, A. N. (1987). Reproductive hormone responses to resistance exercise. Medicine and science in sports and exercise, 19(3), 234-238.

Di Luigi, L., Romanelli, F., Sgrò, P., ve Lenzi, A. (2012). Andrological aspects of physical exercise and sport medicine. Endocrine, 42(2), 278-284. Doi: 10.1007/s12020-012-9655-6. Epub 2012 Mar 20.

Enns, D. L., ve Tiidus, P. M. (2010). The influence of estrogen on skeletal muscle. Sports medicine, 40(1), 41-58. Doi: 10.2165/11319760-000000000-00000

FitzGerald, L. Z., Robbins, W. A., Kesner, J. S., ve Xun, L. (2012). Reproductive hormones and interleukin-6 in serious leisure male athletes. European journal of applied physiology, 112(11), 3765-3773.

Doi: 10.1007/s00421-012-2356-2. Epub 2012 Mar 1.

Frappier, J., Toupin, I., Levy, J. J., Aubertin-Leheudre, M., ve Karelis, A. D. (2013). Energy expenditure during sexual activity in young healthy couples. PLoS one, 24;8(10), e79342.

Doi: 10.1371/journal.pone.0079342. eCollection 2013.

Gooren, L. J. (2008). Olympic sports and transsexuals. Asian journal of andrology, 10(3), 427-432.

Doi: $10.1111 /$ j.1745-7262.2008.00378.x.

Gooren, L. J., ve Bunck, M. C. (2004). Transsexuals and competitive sports. European Journal of Endocrinology, 151(4), 425-429. Doi: 10.1530/eje.0.1510425.

Grandys, M., Majerczak, J., Duda, K., Zapart-Bukowska, J., Kulpa, J., ve Zoladz, J. A. (2009). Endurance training of moderate intensity increases testosterone concentration in young, healthy men. International journal of sports medicine, 30(07), 489-495. Doi: 10.1055/s-0029-1202340. Epub 2009 Mar 19.

Hackney, A. C. (2008). Effects of endurance exercise on the reproductive system of men: the "exercise-hypogonadal male condition". Journal of endocrinological investigation, 31(10), 932-938. Doi: 10.1007/BF03346444.

Jones, B. A., Arcelus, J., Bouman, W. P., ve Haycraft, E. (2017). Sport and transgender people: A systematic review of the literature relating to sport participation and competitive sport policies. Sports Medicine, 47(4), 701716. Doi: 10.1007/s40279-016-0621-y.

Kraemer, W. J., Fleck, S. J. ve Deschenes, M. R. (2011). Exercise physiology: Integrating theory and application. Philadelphia: Lippincott Williams \& Wilkins.p. 217-218. 
Gümüş, B.H., Dinç, N. ve Güzel Gürbüz, P. (2020). Sporda hormonal etkileşim ve cinsel davranış. Avrasya Spor Bilimleri ve Eğitim Dergisi, 2(2), 107-117.

Kraemer, W. J., ve Ratamess, N. A. (2005). Hormonal responses and adaptations to resistance exercise and training. Sports medicine, 35(4), 339-361. Doi: 10.2165/00007256-200535040-00004.

Krieger, L. (1997). Scoring before a big event. Winning, 1, 88-89.

Kuyper, L., ve Wijsen, C. (2014). Gender identities and gender dysphoria in the Netherlands. Archives of sexual behavior, 43(2), 377-385. Doi: 10.1007/s10508-013-0140-y. Epub 2013 Jul 16.

Lapauw, B., Taes, Y., Simoens, S., Van Caenegem, E., Weyers, S., Goemaere, S., ... ve T'Sjoen, G. G. (2008). Body composition, volumetric and areal bone parameters in male-to-female transsexual persons. Bone, 43(6), 1016-1021. Doi: 10.1016/j.bone.2008.09.001. Epub 2008 Sep 16.

Ljungqvist, A., ve Genel, M. (2005). Essay: Transsexual athletes-when is competition fair?. The Lancet, 366, S42S43. Doi: 10.1016/S0140-6736(05)67844-0.

Nindl, B. C., Kraemer, W. J., Gotshalk, L. A., Marx, J. O., Volek, J. S., Bush, J. A., ... ve Fleck, S. J. (2001). Testosterone responses after resistance exercise in women: influence of regional fat distribution. International journal of sport nutrition and exercise metabolism, 11(4), 451-465.

Doi: 10.1123/ijsnem.11.4.451.

Powers, S. K., ve Howley, E. T. (2018). Exercise physiology: Theory and application to fitness and performance (10. baskl). New York, NJ: McGraw-Hill Higher Education. s:108

Reeser, J. C. (2005). Gender identity and sport: is the playing field level?. British Journal of Sports Medicine, 39(10), 695-699. Doi: 10.1136/bjsm.2005.018119.

Safarinejad, M. R., Azma, K., ve Kolahi, A. A. (2009). The effects of intensive, long-term treadmill running on reproductive hormones, hypothalamus-pituitary-testis axis, and semen quality: a randomized controlled study. Journal of Endocrinology, 200(3), 259. Doi: 10.1677/JOE-08-0477. Epub 2008 Dec 9.

Sansone, A., Sansone, M., Vaamonde, D., Sgrò, P., Salzano, C., Romanelli, F., ... ve Di Luigi, L. (2018). Sport, doping and male fertility. Reproductive Biology and Endocrinology, 16(1), 114.

Doi: 10.1186/s12958-018-0435-x.

Sokoloff, N. C., Misra, M., ve Ackerman, K. E. (2016). Exercise, training, and the hypothalamic-pituitary-gonadal axis in men and women. Front Horm Res, 47, 27-43. Doi: 10.1159/000445154.

Stefani, L., Galanti, G., Padulo, J., Bragazzi, N. L., ve Maffulli, N. (2016). Sexual activity before sports competition: a systematic review. Frontiers in physiology, 7, 246, 1-8. Doi: 10.3389/fphys.2016.00246.

Turek JP. (2014). Campbell-Walsh Üroloji. Yaman Ö. (ed), Erkek reprodüktif fizyolojisi. (1. Baskl). Ankara. Güneş Kitabevi. s.591-615.

Wood, R. I., ve Stanton, S. J. (2012). Testosterone and sport: current perspectives. Hormones and behavior, 61(1), 147-155. Doi: 10.1016/j.yhbeh.2011.09.010. Epub 2011 Oct 1.

Velders, M., ve Diel, P. (2013). How sex hormones promote skeletal muscle regeneration. Sports medicine, 43(11), 1089-1100. Doi: 10.1007/s40279-013-0081-6.

Zavorsky, G. S., ve Newton, W. L. (2018). Effects of sexual activity on several measures of physical performance in young adult males. The Journal of sports medicine and physical fitness, 59(7), 1102-1109.

Doi:https://doi.org/10.1016/j.esxm.2018.12.002.

Zitzmann, M., ve Nieschlag, E. (2003). Effects of androgen replacement on metabolism and physical performances in male hypogonadism. Journal of endocrinological investigation, 26(9), 886-892.

Doi: 10.1007/BF03345240. 


\section{EXTENDED ENGLISH SUMMARY}

Since ancient times, physiological and psychological dimensions of behavioral models that affect the success criteria of sports activity and their diversity has been investigated. Today, studies based on broader criteria on this subject continue. Even in the context of modern life it is difficult to find a roadmap to research and guide how to regulate sexual activity habits if you are involved in sports competitions either as an amateur or as professional occupation. The main reason to this is the difficulty in reaching volunteers because of the privacy of the subject which requires great attention. This study aims to review the relationship between sexual activity and hormonal changes that shape behavior and reproductive drive in human biochemistry with sportive activity in the sphere of the current literature data. One of the questions that sports coaches, technical trainers and scientists are interested in and try to answer is whether sexual activity affects athletic performance before the competition. Having few published data on the subject makes it difficult to provide a clear opinion due to methodological differences in these studies. Testosterone and estrogen are sexual steroids secreted by the testicles and ovaries, respectively. Testosterone is both anabolic (tissue building) and androgenic (supportive of masculine properties) steroid in men. It stimulates protein synthesis and increases muscle mass. When the effects of training on testosterone secretion are examined, it is observed that there is an increase in testosterone levels after acute exercises, while contradictory results appear in research after chronic exercises, and these contradictory results are due to the athlete's fitness level, training volume and intensity and excessive training status. Besides, long-term use of anabolicandrogenic steroids, which are banned from outside use to increase performance, causes many medical problems. Hormonal concentration values should be checked further regarding the duration and intensity of sports activities. The abuse of some substances must be prevented and the relevant parties must be informed about their possible dangers. Sports cannot be sustained professionally for life, but the damage caused by these substances can be permanent. It is obvious that larger patient groups and parameters are needed for gender changes and sports activity association. Young sports scientists will contribute to science by carrying out new studies in these areas by considering the traditional judicial values of the society in which they live.

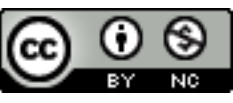

Except where otherwise noted, this paper is licensed under a Creative Commons Attribution 4.0 International license. 